\title{
IMPLEMENTASI RATIONAL EMOTIF BEHAVIORAL THERAPY (REBT) \\ TERHADAP PENGURANGAN TINGKAT KECEMASAN KLIEN “AS" \\ PASCA BENCANA LONGSOR DI DESA MARGAMUKTI KECAMATAN PANGALENGAN KABUPATEN BANDUNG BARAT
}

\author{
Uut Hanafi Rochman \\ Universitas Binawan \\ Email: $\underline{\text { uut@binawan.ac.id }}$
}

\begin{abstract}
Abstrak
Penelitian ini bertujuan untuk mengetahui implementasi Rational Emotive Behavior Therapy (REBT) terhadap pengurangan tingkat kecemasan yang dialami oleh klien AS pasca bencana longsor di desa Margamukti Pangalengan. Pasca bencana longsor klien AS mengalami indikasi gangguan kecemasan. Hampir setiap orang mengalami gangguan kecemasan yang ditandai dengan kekhawatiran, kegelisahan yang berdampak pada gangguan emosional, kognitif dan fisiologis yang disebabkan oleh faktor masa lalu. Penelitian ini menggunakan pendekatan kuantitatif dengan desain penelitian eksperimen. Dalam penelitian ini penelitian menggunakan single subject design (SSD) dengan teknik reselval (desain dengan pegulangan) dengan model A-B-A. Hasil penelitian menunjukkan bahwa setelah dilaksanakannya intervensi berupa terapi REBT tingkat kecemasan yang dialami oleh klien AS mengalami kecemasan, dimana pada baseline A1 yang tadinya masuk kategori tinggi dengan skor 22 menjadi kategori sedang dengan skor 11 pada fase akhir dibaseline A2. Dari data tersebut menjelaskan bahwa implementasi terapi REBT mempengaruhi penurunan tingkat kecemasan pada penyintas pasca bencana.
\end{abstract}

Kata Kunci: Rational Emotive Behavior Therapy (REBT), Tingkat Kecemasan, Klien AS, Pasca Bencana Longsor.

\begin{abstract}
This study aims to determine the implementation of Rational Emotive Behavior Therapy (REBT) to reduce the level of anxiety experienced by US clients after landslides in Margamukti Pangalengan village. After the landslide, the US client experienced indications of anxiety disorders. Almost everyone experiences an anxiety disorder characterized by anxiety, restlessness that has an impact on emotional, cognitive and physiological disorders caused by past factors. This study uses a quantitative approach with an experimental research design. In this study, the study used a single subject design (SSD) with reselval technique (design with repetition) with the A-B-A model. The results showed that after the implementation of the intervention in the form of REBT therapy, the level of anxiety experienced by US clients experienced anxiety, where at baseline A1, which was in the high category with a score of 22, became the moderate category with a score of 11 in the final phase in the A2 baseline. From these data, it explains that the implementation of REBT therapy affects the reduction of anxiety levels in post-disaster survivors.
\end{abstract}

Keywords: Rational Emotive Behavior Therapy (REBT), Anxiety Level, AS Client, Post Landslide Disaster. 


\section{A. PENDAHULUAN}

Bencana tanah longsor merupakan masalah yang serius, kejadiannya mengalami peningkatan dari tahun ke tahun. Provinsi Jawa Barat merupakan salah satu daerah rawan bencana di Indonesia. Berdasarkan data dari BNPB, sepanjang tahun 2016 terdapat 17 kejadian bencana di semua klaster. Terdapat 26 kabupaten/kota telah mengalami terjadinya suatu bencana. Salah satu bencana yang terjadi di Bandung yaitu bencana longsor yang banyak menelan korban jiwa. Terdapat 795 korban meninggal, 79 orang dinyatakan hilang, 735 jiwa mengalami luka-luka dan 32.150 jiwa mengungsi.

Menurut BNPB tahun 2016, terdapat 6 kejadian bencana di Kabupaten Bandung seperti banjir, gempa bumi, kebakaran, kekeringan, puting beliung dan tanah longsor. Untuk bencana longsor di Kabupaten Bandung telah menelan 31 korban meninggal, 5 orang di nyatakan hilang, 63 mengalami lula-luka dan 916 KK mengungsi. Bencana yang terjadi telah menyebabkan kerugian materi, fisik maupun dampak psikologis. Penyebab terjadinya bencana longsor salah satunya dikarenakan munculnya retakan-retakan dilereng serta hujan yang terjadi secara terus menerus.

Pada tanggal 5 Mei 2015 terjadi bencana tanah longsor di Desa Margamukti Kecamatan Pangalengan Kabupaten Bandung Provinsi Jawa Barat. Bencana tanah longsor yang disertai ledakan pipa gas bumi oleh PT Star Energi telah menyebabkan 54 KK mengungsi, 10 orang luka - luka, 7 orang korban meninggal dan 3 orang hingga kini belum ditemukan. Kerugian yang ditimbulkan tidak sedikit, banyaknya warga yang kehilangan tempat tinggal, harta benda, mata pencaharian, serta terhambatnya aktivitas sehari-hari.

Upaya pemulihan sosial psikologis pasca bencana khususnya di Kampung Cibitung Desa Margamukti Kecamatan Pangalengan telah dilakukan oleh peneliti. Hal ini dimaksudkan untuk meningkatkan keberfungsian penyintas pasca bencana longsor serta mengurangi gejala-gejala psikis seperti upaya untuk mengelak dari kegiatan atau situasi yang menimbulkan ingatan terhadap peristiwa bencana longsor, perasaan terasing dari orang lain, sulit berkonsentrasi, mudah marah, serta kewaspadaan yang berlebihan. Hal ini ditujukan karena terdapat masyarakat di Desa Margamukti yang tinggal di daerah rawan bencana longsor seperti topografi kemiringan tanah dan pemukiman penduduk berada dalam lahan yang menurun, memiliki bentuk permukaan, berombak, perbukitan dan pegunungan yang diperoleh dari profil Desa Margamukti Tahun 2014.

Bencana tanah longsor di Kampung Cibitung Desa Margamukti Kecamatan Pangalengan telah berlalu, namun sebagian masyarakat belum dapat melupakan kejadian tersebut. Namun demikian jika hal tersebut menyebabkan gejala-gejala gangguan psikis 
yang dapat menghambat keberfungsian sosialnya maka perlu dilakukan penanganan lebih lanjut. Hal ini seperti dialami oleh responden AS yang menjadi penyintas longsor di Kampung Cibitung Desa Margamukti Kecamatan Pangalengan.

Berdasarkan hasil asesmen, responden AS mengalami gejala-gejala psikis seperti perasaan menyalahkan diri sendiri, menyalahkan pihak tertentu, merasa tidak dihargai, bantuan atau rehabilitasi dan rekontrusi tidak kunjung terlaksanan seperti yang telah dijanjikan, krisis kepercayaan terhadap pihak-pihak tertentu, serta merasa di jadikan obyek dalam penanggulangan bencana.

Selain faktor-faktor tersebut diatas, responden AS juga dihadapkan pada peristiwa yang mengancam dirinya seperti guncangan yang disebabkan oleh penambangan gas bumi oleh PT Star energy, sirine yang terdengar dari PT Starenergi, adanya gempa yang dirasakan oleh responden turut memicu gangguan kecemasan yang muncul. Hal ini di tunjukan pada hasil postes dan pretes bahwa tingkat kecemasan responden berada pada kategori tinggi yaitu kecemasan secara kognitif mencapai 70\%-90\% dengan indikator kegelisahan, secara emosional 66\%-78\% dan aspek fisiologis 58\%-75\%.

Hal tersebut menunjukan bahwa responden AS mudah terbawa situasi, adanya gejala-gejala gangguan kecemasan pada responden AS seperti sulitnya klien untuk berkonsentrasi yang menyebabkan responden AS mudah lupa, sering membayangkan ketika orang yang ia sayangi masih hidup, takut ketika mendengar suara gemuruh sehingga berdampak pada responden AS yaitu gangguan tidur jika hujan turun, memiliki pandangan negatif terhadap pemerintahan, merasa tertekan dengan keadaan tanpa mengetahui penyebabnya. Bencana longsor telah berlalu, namun Responden AS menunjukan gejalagejala ganguan kecemasan. Menrut Giller dalam Triantoro (2012), menjelaskan bahwa trauma secara psikologis adalah pengalaman individu yang unik dari satu kejadian atau peristiwa yang meliputi 1) ketidak mampuan individu untuk mengintegrasikan pengalaman emosional 2) pengalaman individu secara subjektif yang mengancam hidup, kebutuhan jasmaniah atau kesejhatan jiwanya.

Dengan demikian perlunya dilakukan intervensi melalui terapi yang dapat mengurangi gangguan kecemasan pada responden AS. Salah satu teknik terapi yang melihat hubungan antara gangguan emosi, pikiran dan perilaku yaitu Rational Emotive Behavior Therapy (REBT). Dasar pemikiran Rational Emotive Behavior Therapy (REBT) yaitu emosi dan fisiologis merupakan hasil proses dari Kognitif. Menurut Elis, dalam Hirmaningsih dkk (2015), Rational Emotive Behavior Therapy (REBT) menggabungkan tiga teknik yaitu kognitif, emotif dan tingkah laku sehingga pemikiran-pemikiran irasional subjek mengenai 
diri seseorang akan diubah mnjadi pikiran rasional dan juga mengubah emosi negatif menjadi emosi yang positif dan keduanya akan terlihat dari perilaku yang di tunjukan oleh subjek. Berkaitan dengan hal tersebut, maka peneiti tertarik untuk melaksanakan peneliian implementasi Rational Emotive Behavior Therapy (REBT) terhadap responden AS pasca bencana longsor di Kampung Cibitung Desa Margamukti Kecamatan Pangalengan Kabupaten Bandung.

\section{B. METODE}

Berdasarkan latar belakang yang telah diuraikan, maka fokus penelitian ini adalah “ Bagimana implementasi Rational Emotive Behavior Therapy (REBT) terhadap Responden AS pasca bencana longsor di Kampung Cibitung Desa Margamukti Kecamatan Pangalengan Kabupaten Bandung" Untuk mengetahui permasalahan secara mendalam, maka peneliti mengajukan beberapa sub problematik antara lain karakteristik responden, implementasi Rational Emotive Behavior Therapy (REBT) terhadap kondisi kognitif responden AS pasca bencana longsor, implementasi Rational Emotive Behavior Therapy (REBT) terhadap kondisi emosi responden AS pasca bencana longsor, Implementasi Rational Emotive Behavior Therapy (REBT) terhadap kondisi perilaku responden AS pasca bencana longsor

Berdasarkan uraian rumusan permasalahan, asusmsi dasar yang digunakan dalam penelitian ini yaitu Rational Emotive Behavior Therapy (REBT) merupakan salah satu teknik terapi yang menggabungkan pendekatan cognitive dan pendekatan behavioral. Elies \& Dyren dalam jurnal Hirmaningsih dkk menjelaskan, Rational Emotive Behavior Therapy (REBT) menggabungkan tiga teknik yaitu teknik kognitif, emosi dan perilaku, sehingga pikiran pikiran irasional subjek mengenai dirinya akan di ubah menjadi pikiran yang rasional serta merubah emosi negati menjadi emosi yang positif dan ditunjukan dnegan perilaku subyek. Menurut Ellis (2007); Rational Emotive Behavior Therapy (REBT) dapat digunakan dalam mengatasi berbagai masalah, salah satunya yaitu gangguan kecemasan maupun mengurangi faktor-faktor yang memengaruhi kecemasan. Menurut Elis, dalam Gladding (2012), mengembangkan teori A-B-C-D-E dari Rational Emotive Behavior Therapy (REBT) yaitu activating event, beliefs, consequences, disputing, dan affective.

Penelitian ini bertujuan memperoleh gambaran tentang pengaruh rational emotif behavioral therapy (REBT) terhadap Klien As korban pascabencana longsor. Berdasarkan tujuan penelitian, maka penelitian ini menggunakan eksperimen. Penelitian eksperimen merupakan kegiatan percobaan untuk meneliti suatu peristiwa atau gejala yang muncul pada kondisi atau situasi tertentu. Menurut Ronsow \& Rosenthal, desain penelitian eksperimen 
secara garis besar dapat dibedakan menjadi dua kelompok yaitu desain kelompok (group desain) dan desain subjek tunggal (single subjek design) (Sunanto, 2005). Desain kelompok memfokuskan pada data yang berasal dari kelompok individu sedangkan desain subjek tunggal (single subjek design) memfokuskan pada data yang individu sebagai sampel penelitian.

Desain penelitian dengan menggunakan Single Subject Design (SSD) atau desain subyek tunggal menurut Sunanto (2005), yaitu jika subyek penelitian tersebut bersifat tunggal, maka desain penelitian yang di gunakan adalah SSD dengan menggunakan sampel N=1 (Ronsow \& Rosenthal, dalam Sunanto, 2005). Untuk memecahkan permasalahan klien As, maka peneliti mengguanakan single subject design (SSD) dengan teknik reselval (desain dengan pegulangan) dengan model A-B-A, selain hal tersebut untuk mengukur target pikiran rasional dalam penelitian ini menggunakan baseline (A) yaitu kondisi gejala gangguan kecemasan sebelum di intervensi, kondisi intervensi (B) yaitu gejala gangguan kecemasan pada saat intervensi dan setelah dilakukan pengukuran baseline setelah intervesni (A2) yaitu kondisi gejala gangguan kecemasan klien As setelah dilaksanakannya intervensi.

Penjelasan tersebut disesuaikan dengan pengertian baseline dan kondisi eksperimen menurut Hasselt \& Harsen Juang Sunanto (2005) yaitu: Kondisi dimana pengukuran target behavior dilakukan pada keadaan natural sebelum diberikan intervensi apapun. Kondisi eksperimen adalah kondisi dimana suatu intervensi telah diberikan dan target behavior di ukur dibawah kondisi tersebut. Pada penelitian dengan desain SSD selalu dilakukan perbandingan antara baseline dengan sekurang-kurangnya satu fase intervensi.

Berkaitan dengan pemecahan masalah penelitian yang diajukan dengan bentuk A-BA menunjukan adanya sebab-akibat. Prosedur utama dalam desain A-B-A dapat digambar seperti grafik dibawah ini

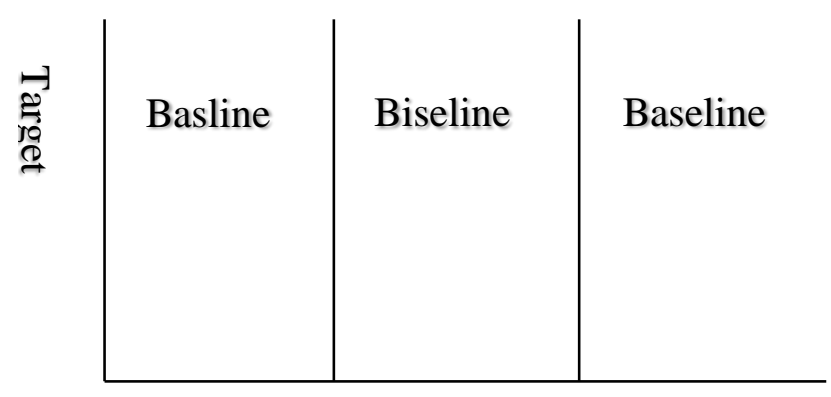

(Juang Sunanto

Gambar 1 Prsedur Dasar A-B-A 
Prosedur dasar tersebut, dalam melakukan penelitian dengan desain kaus tunggal menurut Hasselt\& Harsen, dalam Sunanto (2005), menjelaskan bahwa selalu ada pengukuran target pencapaian behavior pada fase baseline dan pengulangannya sekurang-kurangnya satu fase intervensi. Hal ini menunjukan bahwa penilaian tingkat keberhasilan intervensi, peneliti harus mengetahui kondisi subyek penelitian sebelum dilaksanakannya intervensi. Pencapaian peneliti dalam melakukan penelitian eksperimen tersebut perlu memperhatikan langkah langkah sebagai penelitian.

\section{HASIL DAN PEMBAHASAN}

\section{Latar Belakang Responden}

Klien AS lahir pada tahun 1977, AS merupakan anak terakhir dari tujuh bersaudara dan semuanya telah berkeluarga. AS tinggal bersama suami, oarngtua (I) dan putra nya (D) 20 tahun serta (S) 13 tahun. Mereka bertempat tinggal di lingkungan yang sama dan rumahnya saling berdekatan. AS menikah dengan AH pada usia 18 tahun. AS tinggal di Kampung Cibitung RT 01/15 Desa Margamukti Kecamatan Pangalengan Kabupaten Bandung sudah 38 tahun. Selama AS tinggal di kampung tersebut, beliau merasakan kenyamanan dan rasa aman tanpa di selimuti ancaman maupun kerentanan terhadap bencana longsor.

Satu bulan sebelum terjadinya bencana longsor, Desa Margamukti khususnya kampung Cibitung mendapat peringatan dini dari BPBD terkait dengan adanya retakan tanah sepanjang $+2 \mathrm{~km}$ dengan kedalaman 2-5 m. Dengan adanya peringatan dini tersebut, masyarakat di himbau untuk selalu waspada terhadap bahaya bencana longsor terlebih jika hujan terus menerus.

Pada tanggal 5 Mei tepatnya pukul 14.50 WIB ledakan keras terjadi di kampung tersebut. warga kampung Cibitung berhamburan menyelamatkan diri termasuk AS. Pada hari itu telah terjadi bencana longsor dan di ikuti ledakan pipa gas bumi milik Star Energi yang tidak jauh dari pemukiman penduduk. Responden AS turut menjadi korban dahsyatnya bencana longsor.

Pada saat terjadinya longsor AS sedang berada di dalam rumah bersama I 60 tahun dan S 13 tahun. Tangisan histeris, ketakutan dan kebingungan semakin mencekam di kampung Cibitung. Korban berjatuhan rumah rusak-rusak turut menjadi saksi AS. AS sempat terpisah dengan anggota keluarganya. AS semakin tidak berdaya ketika melihat anaknya D (20 tahun) terluka karena menyelamatkan diri. 
Perstiwa bencana longsor yang terjadi pada tanggal 5 Mei 2015, sontak tidak dapat AS Lupakan. AS telah menjadi korban bencana longsor tersebut. AS kehilangan harta benda, tempat tinggalnya dan bahkan kehlangan anggota keluarganya. Kakak ke 5 (R) 40 Tahun mengalami luka berat, AS juga kehilanggan Kakak ke 6. Bencana tersebut memberikan ketakutan yang mendalam bagi AS dan keluarga.

Satu jam setelah terjadnya longsor tersebut, seluruh warga kampung cibitung di ungsikan di aula Desa Margamukti, hal tersebut dilakukan karena lokasi desa yang berada di daerah aman serta cukup untuk menampung $54 \mathrm{KK}$. Pada saat tanggap darurat AS mengalami kekhawatiran karena tidak lagi memiliki rumah, merasa kehilangan segalanya bahkan mencemaskan kondisi keluarga kakanya yang meninggal. AS merasa enggan kembali ke lokasi longsor karena takut akan terjadi bencana longsor susulan bahkan AS enggan untuk mengingat kembali musibah yang menimpanya. AS ingin kembali hidup normal seperti semula. Pasca bencana longsor AS dan keluarga tinggal di kontrakan.

Kekecewaan kembali menyelimuti perasaannya. Relokasi yang di janjikan tidak kunjung dilaksanakan, bantuan berupa santunan untuk mengontrak rumah baru di berikan sebagian. AS merasa tidak berdaya, harapnnya seperti sudah pupus pascabencana longsor.

AS memiliki keluarga yang berasal dari keluarga sederhana. Ayah AS dulunya bekerja sebagai buruh perkebunan the PTPN Malabar dan mendapatkan rumah Dinas di Kampung Cibitung Desa Margamukti. Ayahnya meninggal ketika AS berusia 27 tahun. Ibu AS yang sekarang sudah lansia tidaklagi dapat beraktifitas seperti sedia kala karena terkena rematik pada bagian kaki sehingga memerlukan bantuan responden AS.

AS memiliki 6 orang kakak yang masing-masing telah berkeluarga. Berdasarkan hasil wawancara dengan subyek, dari ke enam saudaranya hanya 'C' saja yang tidak berkeluarga. Hal tersebut dikarenakan ' $C$ ' telah meninggal dunia pada Usia 17 tahun. Peristiwa kecelakaan telah merenggut nyawa beliau.

Kakak kelima responden turut menjadi menjadi korban bencana longsor, kaki dan tangannya terluka dan sempat dibawakan kerumah sakit. Sedangkan kakaknya meninggal dalam peristiwa tersebut. Berdasarkan keterangan dari responden, kakaknya merupakan korban yang belum di temukan sampai sekarang. Perasaan sedih yang mendalam ditunjukkan oleh responden ketika peneliti menannyakan kembali peristiwa bencana longsor yang terjadi. Selain hal tersebut kakaknya juga memiliki anak yang usianya masih balita. Berdasarkan informasi yang diberikan oleh responden, anak pertama AS mengalami luka pada bagian kepala akibat benturan benda padat ketika sedang menyelamatkan diri. Hal ini ia alami karena merasa panik pada saat peristiwa bencana longsor terjadi. 


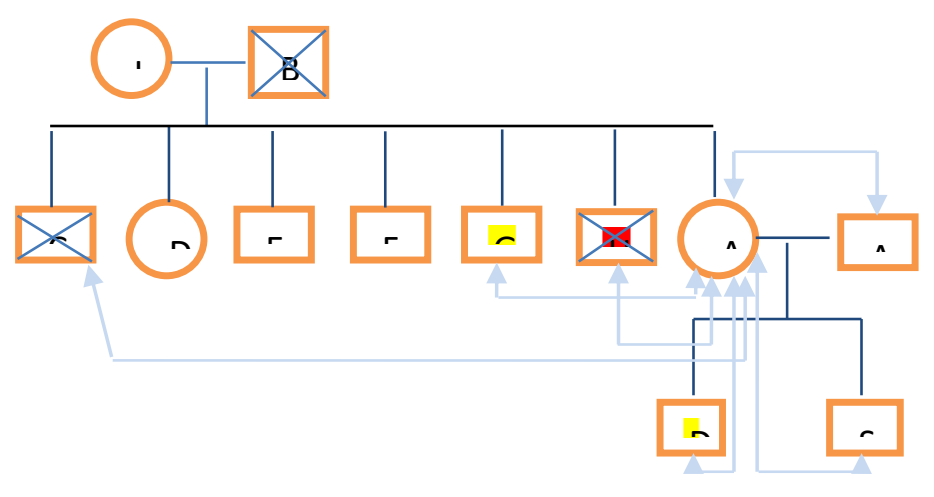

Gambar 2 Genogram 2

Berdasarkan genogram diatas, tanda panah berwarna biru, menjelaskan bahwa terdapat pengaruh yang cukup signifikan antara I sebagai orang tua, G dan $\mathrm{H}$ sebagai kakak dari responden serta $\mathrm{AH}, \mathrm{D}$ dan $\mathrm{S}$ sebagai keluarga inti responden AS. Tanda panah tersebut memberikan pengertian keterkaitan atar penyintas pasca bencana longsor. Hasil Asessment menunjukkan bahwa terdapat keterkaitan munculnya gejala kecemasan yang disebabkan kelekatan keluarga pasca bencana longsor

\section{a. Fase Baseline A1 (Pengukuran tingkat kecemasan sebelum intervensi)}

Dalam pembahasan ini, peneliti mengumpulkan data baseline untuk mengukur tingkat kecemasan responden berkaitan dengan kondisi fisik, kondisi emosional dan perilaku responden pasca bencana longsor di Kampung Cibitung Desa Margamukti. Pengukuran tersebut dilaksanakan sebanyak tiga sesi sebelum dilaksanakannya tahappan intervensi. Hasil pengukuran dapat dijelaskan melalui grafik berdasarkan aspek-aspek kecemasan dalam seiap sesinya.

\section{Pengukuran Sesi I}

Pengukuran sesi I, dilaksanakan pada tanggal 5 April 2017 terhadap responden “AS”. Hasil penelitian menunjukan sebagai berikut:

\section{Aspek kecemasan secara kognitif}

Berkaitan dengan aspek kecemsan secara kognitif, terdapat 9 pernyataan dengan jawaban [Ya] diberi skor 1 dan jawaban [Tidak] diberi skor 0. Responden AS menjawab 9 pernyataan dengan jawaban [Ya]. Pernyataan tersebut menjelaskan tentang kekhawatiran, sulit berkonsentrasi dan membesar-besarkan ancaman. Berdasarkan pengukuran hasil penelitian pada sesi I yaitu sebesar (9) dan berada pada interval tinggi. Maka dipeoleh dari rumus berikut:

$$
\text { Rumus } \quad: \frac{0+9}{3}=3
$$


Keterangan : Interval rendah: 0 - 3

Interval sedang: 4 - 6

Interval tinggi: 7 - 9

Hasil $\quad: 9$

\section{Aspek Kecemasan secara emosional}

Pada asepek kecemasan secara emosioanal terdapat 9 pernyataan. Berdasarkan 9 pertanyaan, responden AS memberikan jawaban yang bervariasi yaitu 6 pernyataan dengan jawaban [Ya] dan tiga pernyataan dengan jawaban [Tidak]. Ke 6 pernyataan tersebut berkaitan dengan perasaan mudah tersinggung, merasa hidupnya hancur pasca bencana, perasaan tidak berguna, sering merasa gelisah serta perasaan khawatir. Berkaitan dengan hal tersebut, hasil pengukuran tingkat kecemasan. Berdasarkan aspek kecemasan emosional pada sesi I sebesar (6) dengan interval sedang. Interval sedang di peroleh melalui rumus:

$$
\begin{aligned}
\text { Rumus } & : \frac{0+9}{3}=3 \\
\text { Keterangan: Interval Rendah } & : 0-3 \\
\text { Interval Sedang } & : 4-6 \\
\text { Interval Tinggi } & : 7-9
\end{aligned}
$$

Hasil $\quad: 6$

\section{Aspek kecemasan secara fisiologis}

Pada aspek kecemasan secara fisiologis, terdapat 12 pernyataan. Berdasarkan variasi jawaban yang di pilih oleh responden AS, terdapat 7 pernyataan dengan jawaban jawaban [Ya] dan 5 pernyataan dengan jawaban [Tidak]. Berkaitan dengan hal tersebut maka pada sesi I terkait aspek kecemasan secara fisiologis sebesar 7 point atau berada pada interval sedang. Hasil tersebut diperoleh melalui rumus sebagai beikut:

$$
\begin{aligned}
& \text { Rumus } \quad: \frac{0+12}{3}=4 \\
& \text { Keterangan : Interval rendah: } 0 \text { - } 4 \\
& \text { Interval sedang: } 5 \text { - } 8 \\
& \text { Interval tinggi : } 9-12 \\
& \text { Hasil } \quad: 7
\end{aligned}
$$

Berdasarkan hasil penelitian maka target pengurangan kecemasan terhadap responden AS pasca bencana longsor Kampung Cibitung Desa Margamukti pada pengukuran data Baseline dapat dilihat pada tabel berikut: 
ARTIKEL

Tabel 1 Hasil Pengukuran Baseline (A1) Instrumen Tingkat Kecemasan Responden AS Tahun 2017

\begin{tabular}{|c|l|c|c|c|}
\hline \multirow{2}{*}{ No. } & \multicolumn{2}{|c|}{$\begin{array}{c}\text { Target pengurangan } \\
\text { kecemasan }\end{array}$} & \multicolumn{3}{|c|}{ Sesi } \\
\cline { 2 - 5 } & $\begin{array}{l}\text { Aspek kecemasan secara } \\
\text { kognitif }\end{array}$ & 9 & 8 & 7 \\
\hline 2. & $\begin{array}{l}\text { Aspek Kecemasan secara } \\
\text { emosional }\end{array}$ & 6 & 7 & 6 \\
\hline 3. & $\begin{array}{l}\text { Aspek kecemasan secara } \\
\text { fisiologis }\end{array}$ & 7 & 9 & 8 \\
\hline \multicolumn{2}{|c|}{ Jumlah } & $\mathbf{2 2}$ & $\mathbf{2 4}$ & $\mathbf{2 1}$ \\
\hline
\end{tabular}

$\begin{array}{ll}\text { Keterangan } & \text { : Interval rendah }: \mathbf{0}-\mathbf{1 0} \\ & \text { : Interval sedang }: \mathbf{1 1}-\mathbf{2 0} \\ & \text { : Interval tinggi }: \mathbf{2 1 - 3 0}\end{array}$

Maka nilai rata-rata $\quad: \frac{22+24+20}{3}=22,3$

Berdasarkan data diatas, maka hasil pengukuran Basline A1 pada responden AS memiliki nilai rata-rata 22,3. Hal ini menunjukkan bahwa target pengurangan kecemasan yaitu semakin rendah nilai atau skor yang diperoleh dari pengukuran instrumen, maka semakin efektif untuk menurunkan target pengurangan kecemasan tersebut. Tabel diatas menjelaskan hasil tiap-tiap sesi sebelum intervensi terdapat perbandingan antara sesi I, sesi II dan sesi III. Namun demikian, hasil tersebut dapat dikatakan stabil, karena tidak adanya perbedaan yang sangat signifikan atau dapat dijelaskan bahwa tidak memiliki perbedaan yang cukup jauh. Berkaitan dengan nilai rata-rata ke 3 sesinya, maka dapat disimpulkan bahwa nilai rata-rata dengan jumlah 22 berada pada interval tinggi.

Hal tersebut memberikan penjelasan adanya target pengurangan kecemasan terhadap aspek kecemasan secara kognitif, emosional dan fisiologis pasca bencana longsor yang menimpa responden AS dua tahun silam. Adapun target yang harus di kurangi seperti responden merasa khawatir akan kondisi keuangannya, merasa tidak sebahagia orang lain, merasa hidupnya hancur sehingga dapat memunculkan perasaan bersalah maupun menghakimi dirisendiri pasca bencana longsor.

Oleh sebab itu, perlunya penyadaran, pemahaman serta bimbingan dalam mengatasi gangguan kecemasan responden yang berasal dari dirinya sendiri yaitu dari kondisi kognitif, emosional dan fisiologisnya. Proses pertolongan akan tercapai jika keluarga dekat juga harus saling memberikan dukungan, memotivasi, memberikan arahan serta turut terlibat agar dapat tercapainya target sasaran yaitu responden dapat mengurangi gangguan kecemasan sehingga dapat meningkatkan keberfungsian sosialnya. Berikut adalah gambaran fase baseline A1 dalam bentuk grafik yang berdasarkan aspek gangguan kecemasan responden AS: 


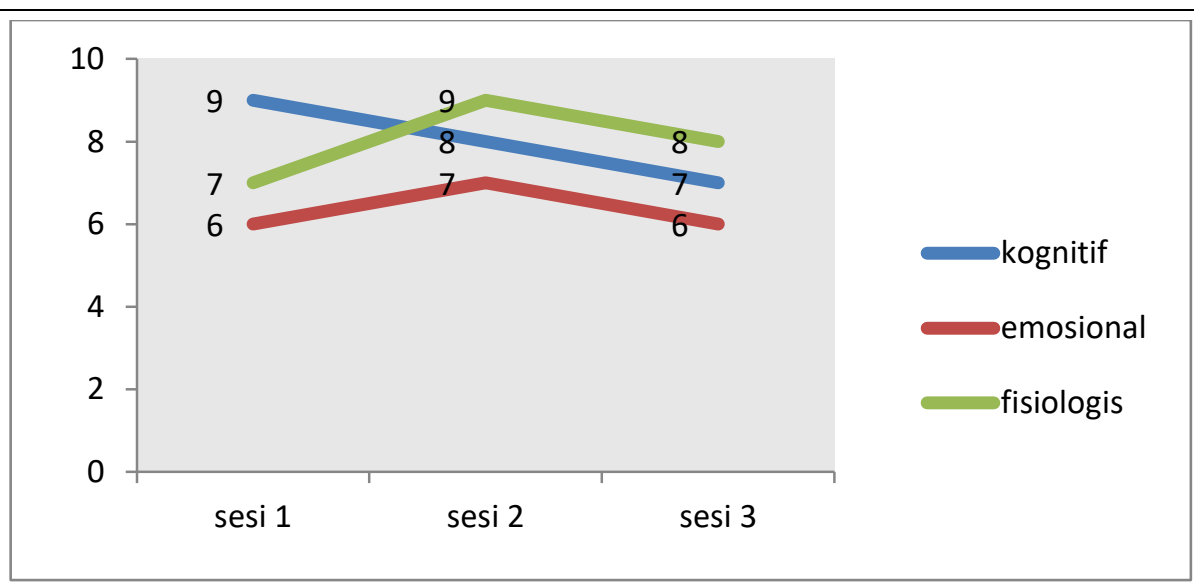

Grafik 1 Instrumen Tingkat Kecemasan Responden AS Berdasarkan Aspek Kecemasan

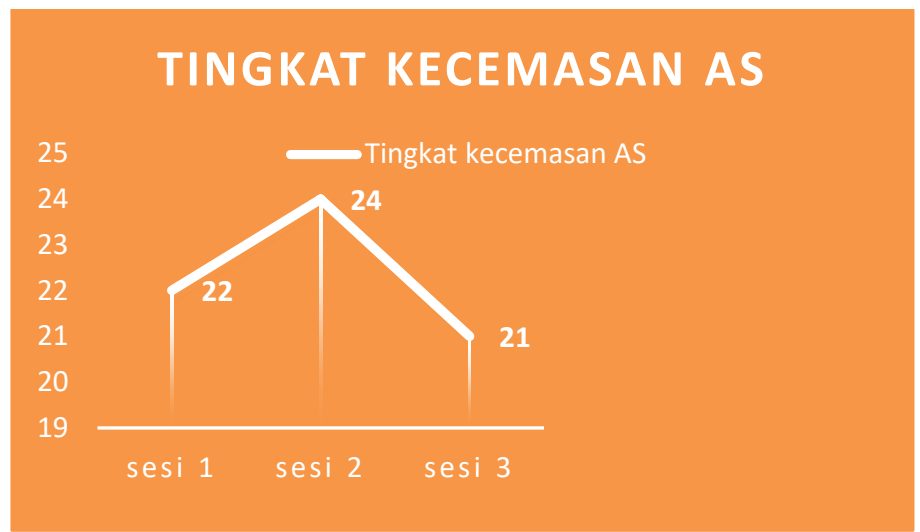

\section{Grafik 2 Baseline (A1) Tingkat Kecemasan Responden AS}

\section{b. Fase Baseline B (Penerapan Teknik REBT)}

Dalam pembahasan ini, peneliti merancang penerapan baseline dengan target pengurangan kecemasan pasca bencana longsor melalui penerapan teknik rational emotif behavior theraphy (REBT). penerapan teknik tersebut dilaksanakan selama +30 hari atau 9 kali pertemuan. Proses ini, merupakan proses yang cukup panjang sehingga diperlukan prosedur dalam proses pertolongan. Prosedur dalam pelaksanakan penerapan teknik rational emotif behavior theraphy (REBT) merupakan hasil kesepakatn peneliti dengan responden AS

\section{Hasil pelaksanaan intervensi}

Berikaitan dengan tahap pelaksanakan, peneliti dan responden menyepakati time schedule pelaksanan. Pelaksanaan program intervensi REBT yaitu dilaksanakan selama 30 hari yaitu dari tanggal 13 April-13 Mei 2017 dengan jangka wakttu +60 menit dalam satu pertemuan. untuk menjelaskan tahapan tiap sesinya, maka dapat dijelaskan sebagai berikut:

Berdasarkan hasil pelaksanaan intervensi pada sesi 1 terhadap responden AS yang berdasarkan ruang lingkup asessmen menggunakan instrument tingkat kecemasan 
ARTIKEL

menunjukkan hasil yang tinggi. Namun demikian dapat dikatakan bahwa tingkat kecemsan yang wajar karena responden disituasikan pada saat bencana terjadi.

Berikut adalah gambaran hasil intervensi pada sesi 1 dalam bentuk tabel dan grafik berdasarkan aspek kognitif; aspek emosional; dan fisiologis:

Tabel 2 Hasil Intervensi REBT terhadap responden AS

\begin{tabular}{|c|c|c|c|c|c|c|c|c|c|c|}
\hline \multirow{2}{*}{ No } & \multirow{2}{*}{ Aspek Kecemasan } & \multicolumn{9}{|c|}{ Sesi } \\
\hline & & 1 & 2 & 3 & 4 & 5 & 6 & 7 & 8 & 9 \\
\hline 1 & $\begin{array}{lr}\text { Kondisi } & \text { kognitif } \\
\text { responden } & \text { AS } \\
\text { pascabencana } & \end{array}$ & 7 & 9 & 6 & 5 & 5 & 6 & 5 & 5 & 4 \\
\hline 2 & $\begin{array}{lr}\text { Kondisi } & \text { emosional } \\
\text { responden } & \text { AS } \\
\text { pascabencana } & \end{array}$ & 6 & 7 & 7 & 7 & 6 & 6 & 5 & 5 & 6 \\
\hline 3 & $\begin{array}{lr}\text { Kondisi } & \text { fisiologis } \\
\text { responden } & \text { AS } \\
\text { pascabencana } & \\
\end{array}$ & 7 & 7 & 6 & 7 & 6 & 8 & 8 & 7 & 6 \\
\hline & Jumlah & 20 & 23 & 19 & 19 & 17 & 20 & 18 & 17 & 16 \\
\hline
\end{tabular}

Pada tabel 2 menggambarkan bahwa dalam rentang sesi 1 sampai 9, menunjukan data yang fluktuatif, dimana penerapan Rational Emotif Behavioral Therapy (REBT) berpengaruh terhadap penurunan tingkat kecemasan responden baik secara kognitif, emosional maupun fisiologis walaupun tidak signifikan penurunan yang ditunjukan dalam setiap sesinya. Berkaitan dengan hasil observasi tersebut, nilai yang di tunjukan oleh respoden sangat bervariasi yaitu dengan nilai tertinggi berada pada sesi dua dan terendah pada sesi ke sembilan. Adapun faktor lain yang turut mempengaruhi dalam proses intervensi, maka faktor lain tersebut turut memberikan pengaruh terhadap naik atau turunnya tingkat kecemasan penyintas pascabencana longsor.

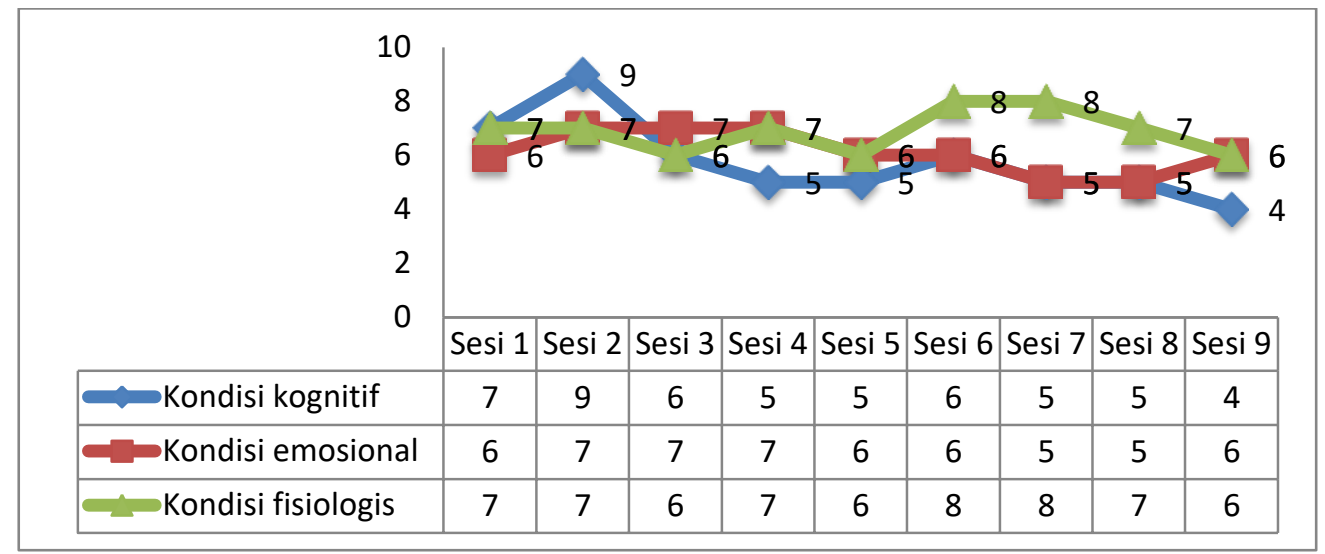

Grafik 3 Hasil Intervensi Masing Masing Aspek Keemasan 
Berdasarkan penjabaran tabel 2, maka diperoleh grafik 3. Hal ini menjelaskan bahwa pada setiap aspek mengalami fluktuatif data. Dari ketiga aspek kecemasan terlihat bahwa aspek yang mengalami penurunan paling dominan terjadi pada aspek kognitif. Hal ini terjadi karena adanya keinginan yang kuat dalam diri ressponden untuk dapat menyelesaikan permasalahannya. Sedangkan untuk aspek emosional dan aspek fisiologis terlihat lebih stabil. Berkaitan dengan hal tersebut maka tingkat kecemasan responden dapat dilihat pada grafik 4

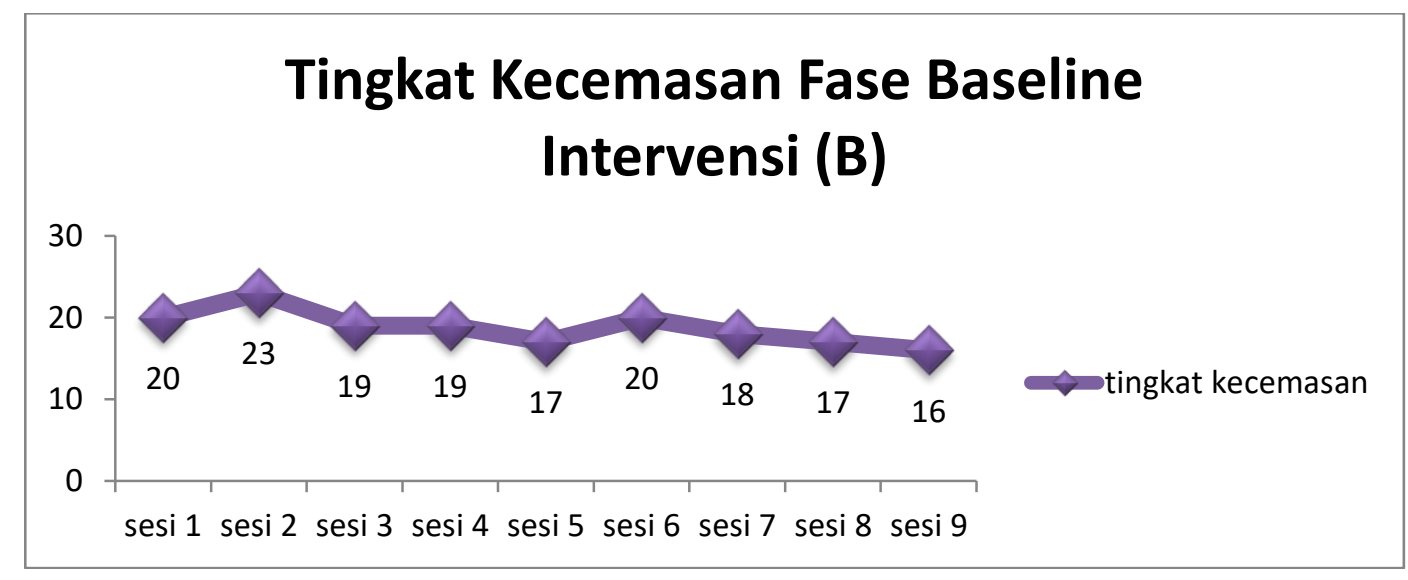

\section{Grafik 4 Tingkat Kecemasan Responden Setelah Dilaksanakan Proses Intervensi}

Berdasarkan grafik 4 menjelaskan bahwa tingkat kecemasan responden AS pada fase baseline B mengalami beberapa kali perubahan tingkat kecemasan. Terlihat bahwa ada waktu tertentu yang menunjukkan peningkatan tingkat kecemasan dan penurunan tingkat kecemasan, walaupun tingkat kecemasan responden AS berada pada kategori sedang

\section{c. Fase Baseline A2 (Penngukuran tingkat kecemasan setelah intervensi)).}

Pada fase Baseline A2, peneliti melakukan pengukuran kembali tingkat kecemasan responden AS setelah dilaksanakannya proses intervensi. Proses pengukuran tingkat kecemasan pada baseline A2, peneliti menggunakan instrument yang sama pada fase baseline A1. Hal ini ditujukan untuk mengetahui tingkat keberhasilan proses intervensi. Pengukuran fase baseline A2 dilaksakan sebanyak 3 sesi yaitu ppada tangga 16, 18 dan 22 Mei 2017.

Berdasarkan pengukuran data baseline dengan target pengurangan kecemasan pasca bencana longsor Kampung Cibitung Desa Margamukti terhadap aspek kecemasan secara kognitif, emosional dan fisiologis, menggunakan instrument baku tingkat kecemasan dapat dilihat pada tabel berikut: 
ARTIKEL

Tabel 3 Hasil Pengukuran Baseline (A2) Instrumen Tingkat Kecemasan Responden AS Tahun 2017

\begin{tabular}{|c|l|c|c|c|}
\hline No. & \multicolumn{2}{|c|}{$\begin{array}{c}\text { Target pengurangan } \\
\text { kecemasan }\end{array}$} & \multicolumn{3}{|c|}{ Sesi } \\
\cline { 2 - 5 } & $\begin{array}{l}\text { Aspek kecemasan secara } \\
\text { kognitif }\end{array}$ & 5 & 4 & 3 \\
\hline 2. & $\begin{array}{l}\text { Aspek Kecemasan secara } \\
\text { emosional }\end{array}$ & 4 & 4 & 4 \\
\hline 3. & $\begin{array}{l}\text { Aspek kecemasan secara } \\
\text { fisiologis }\end{array}$ & 4 & 4 & 4 \\
\hline \multicolumn{1}{|c|}{ Jumlah } & $\mathbf{1 3}$ & $\mathbf{1 2}$ & $\mathbf{1 1}$ \\
\hline
\end{tabular}

Tabel tersebut menunjukan bahwa baseline A2 terdapat 3 sesi. Selama 3 sesi tersebut diperoleh data bahwa dari sesi pertama sampai sesi ketiga cenderung mengalami penurunan skor.hal ini menunjukkan bahwa intervensi yang dilakukan oleh peneliti memberikan dampak yang positif bagi tingkat kecemasan responden AS. Jika tabel 3 dikonversikan dalam bentuk grafik maka akan terlihat seperti grafik 5

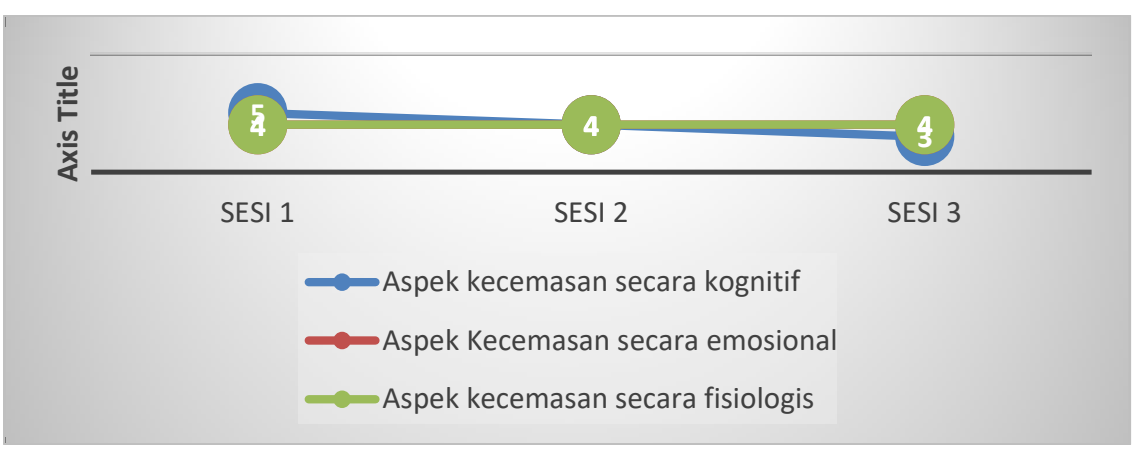

\section{Grafik 5 Baseline (A2) Tingkat Kecemasan Responden ASBerdasarkan Aspek KecemasanTahun 2017}

Grafik 5 menjelaskan tingkat kecemasan responden AS berdasarkan aspek kognitif, mengalami penurunan dari skor 5 menjadi skor 3 sedangkan pada aspek secara emosional dan fisiologis tidak mengalami perubahan. Namun demikian secara keseluruahn tingkat kecemasan responden mengalami penurunan. Hal tersebut dapat dilihat pada grafik 6 . 


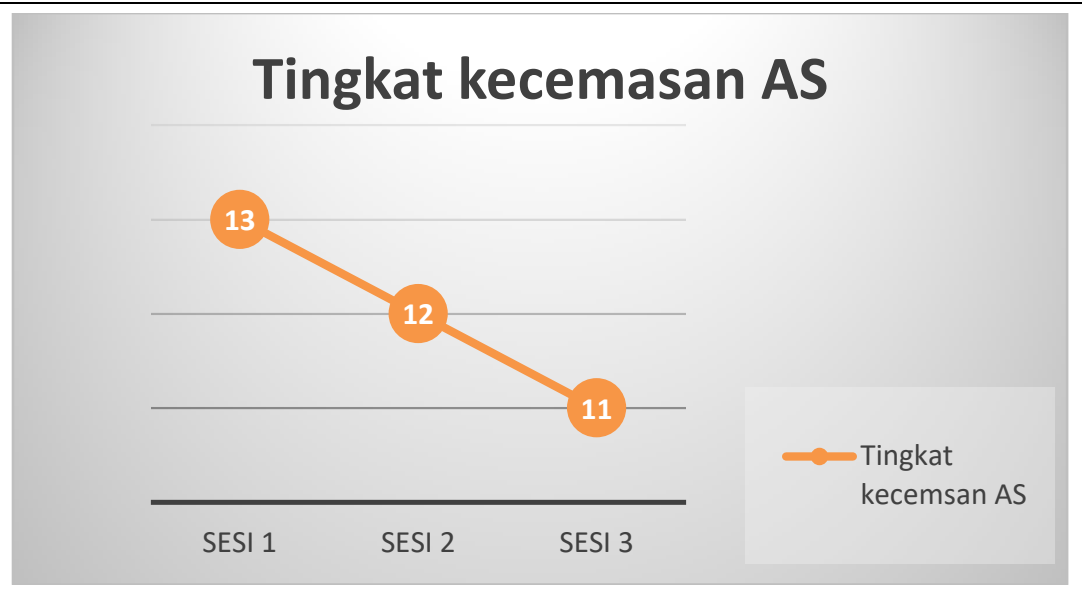

Grafik 6 Baseline (A2) Tingkat Kecemasan Responden AS

\section{Pengaruh Rational emotif behavioral theraphy (REBT) terhadap pengurangan tingkat kecemasan responden AS pasca bencana longsor}

Penelitian ini bertujuan untuk mengetahui pengaruh rational emotif behavioral theraphy (REBT) terhadap pengurangan tingkat kecemasan pasca bencana longsor yang dialami oleh klien AS. Hal ini dapat di lihat melalui tampilan grafik ketika membandingkan sebelum dilaksanakannya intervensi yakni baseline A1, setelah diberikan treatment (B) dan setelah dilaksanakan intervensi (A2).

Berkaitan dengan hal tersebut, hasil penelitian menunjukan dalam penelitian baseline A1 di laksanakan sebanyak 3 sesi, baseline B sebanyak 9 sei dan baseline A2 sebanyak 3 sesi. Tiap sesinya di tunjukan dalam bentuk hari dan selanjutnya di laksanakan observasi. Aspek yang akan dianalisis dalam penelitian ini meliputi: analisis dalam kondisi seperti panjang kondisi, kecenderungan arah, tingkat stabilitas, tingkat perubahanjejak data dan rentang,; analisis antar kondisi seperti variabel yang dirubah, perubahan kecenderungan arah, perubahan stabilitas dan efek, perubahan level dat, serta data yang overlap. Adapaun paparan berdasarkan analisi-analisis tersebut sebagai berikut:

a. Analisis dalam kondisi

1) Panjang Kondisi

Panjang kondisi menunjukan jumlah sesi yang dilakukan dalam tiga fase yaitu fase baseline A1, baseline B dan baseline A2. Berkaitan dengan hal tersebut, maka dapat dilihat berdasarkan tabel 4:

Tabel 4 Panjang Kondisi

\begin{tabular}{|l|c|c|c|}
\hline Kondisi & A1 & B & A2 \\
\hline Panjang kondisi & 3 & 9 & 3 \\
\hline
\end{tabular}


2) Kecenderungan Arah

Untuk mengetahui estimasi kecendurungan arah maka peneliti menggunakan splitmidle dengan cara :

a) Membagi data pada fase baseline menjadi dua bagian yang terdapat di antara dua data

b) Membagi dua pada bagian kanan dan kiri

c) Menentukan posisi median dari masing masing belahan

d) Menrarik garis lurus, mendatar atau menurun dengan absis pada tiap-tiap sesi.

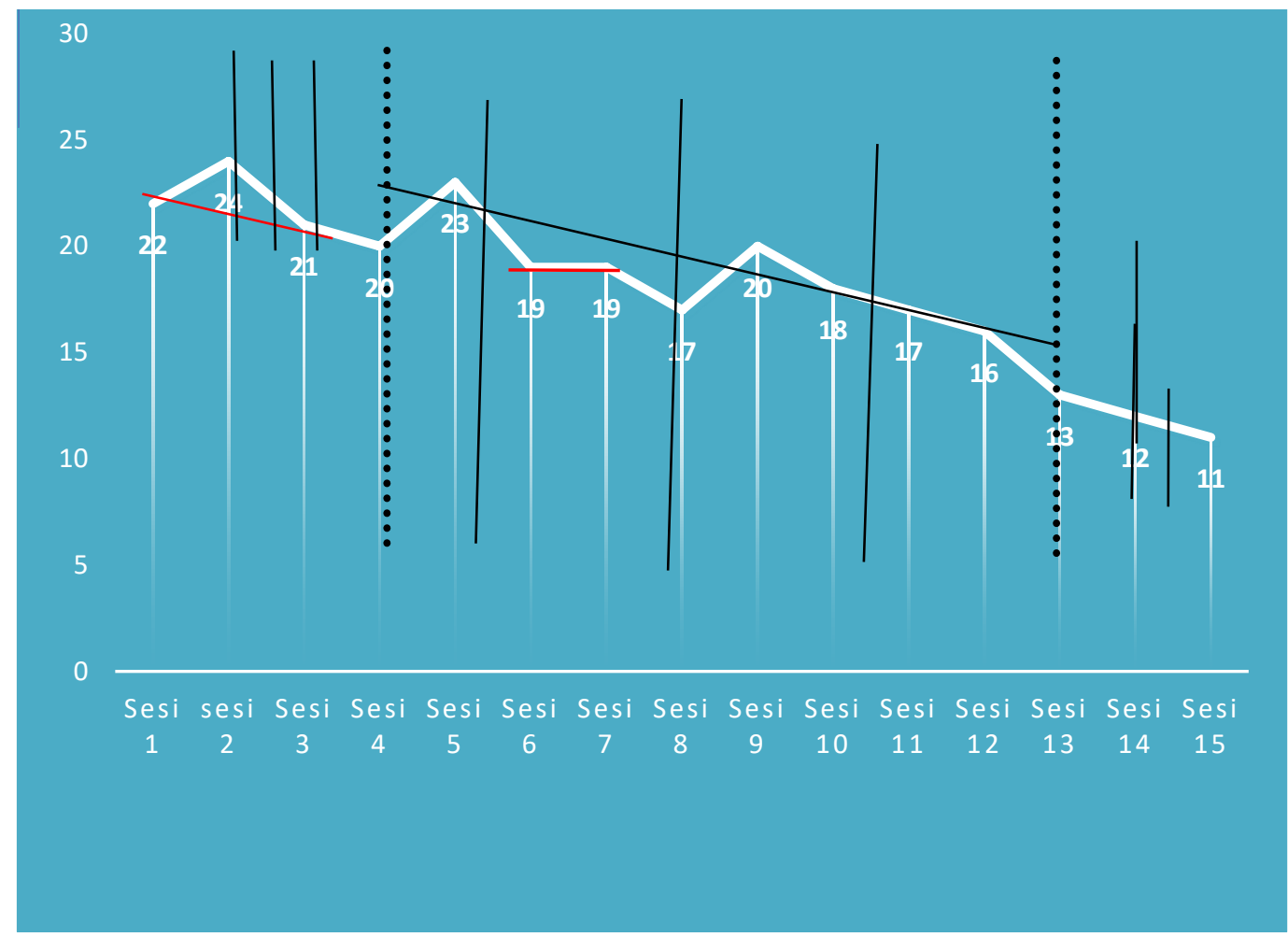

\section{Grafik 7 Estimasi Kecenderungan ArahTingkat Kecemasan April - Juni 2017}

Grafik 7 menjelaskan bahwa pada sesi 1 sampai dengan sesi 3 menunjukan fase baseline A1, sesi 4 sampai sesi 12 merupakan fase baseline B, sedangkan pada sesi 13 sampai sesi 15 merupakan fase baseline A2. Berdasrkan grafik tersebut maka diperoleh data estimasi kecenderungan arah pada tabel 5.

Tabel 5

Data Estimasi secara umum kecenderungan Arah

\begin{tabular}{|l|c|c|c|c|}
\hline Kondisi & A-1 & B & A-2 \\
\hline Estimasi kecenderungan arah & \multicolumn{2}{|c|}{} & $\underset{(+)}{(+)}$ & $(+)$ \\
\hline
\end{tabular}


ARTIKEL

Berdasarkan tabel 5 menjelaskan grafik 7 pada fase baseline A1 menunjukan kecenderungan arah yang positif, fase baseline B menunjukan arah positif dan terdapat persamaan pada sesi 6 dan 7 serta pada fase baseline A2 menunjukkan kecenderungan yang positif.

3) Tingkat Stabilitas

Untuk menentukan tingkat stabilitas kecemasan responden AS dalam kondisi baik baseline maupun intervensi, maka menurut Sunanto (2006), secara umum jika 85\% $90 \%$ data masih berada diatas $15 \%$ dikatakan stabil. Dalam menentukan kecenderungan stabilitas tingkat kecemasan responden AS sebagai berikut:

Skor tertinggi $\mathrm{X}$ Kriteria stabilitas $=$ Rentang Stabilitas

$$
24 \quad 15 \% \quad 3,6
$$

Mean level: $22+24+21=67 / 3=22,3$

Maka batas atas : 22,3 $+1,8=24,1$ sedangkan batas bawah 22,3 $-1,8=20,5$

Point rentang : Banyaknya Data = Presentase Stabilitas

\begin{tabular}{lcc}
\hline \multicolumn{1}{c}{3} & 3 & $100 \%$ \\
\multicolumn{1}{c}{ Kondisi } & A1 & B \\
\hline $\begin{array}{l}\text { Kecenderungan } \\
\text { stabilitas }\end{array}$ & Stabil & Stabil \\
\hline \multicolumn{1}{c}{ Kondisi } & $100 \%$ & $77,77 \%$ \\
\hline $\begin{array}{l}\text { Kecenderungan } \\
\text { stabilitas }\end{array}$ & B & A2 \\
\hline & Stabil & Stabil \\
\hline
\end{tabular}

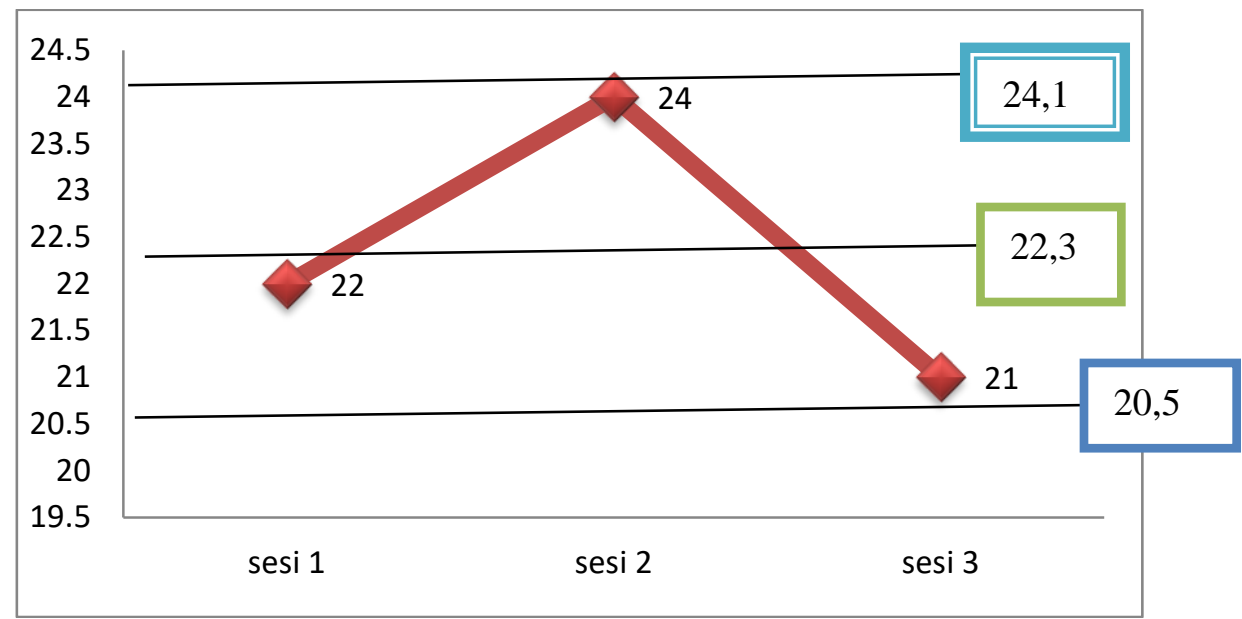

Grafik 8 Tingkat Stabilitas Baseline A1 
ARTIKEL

Berdasarkan grafik 8 pada fase baseline A1 menjelaskan bahwa sesi 1 sampai sesi 3 berada pada garis batas atas dan garis batas bawah. Berkaitan dengan hal tersebut fase baseline A1 berada pada tingkat stabilitas $100 \%$.

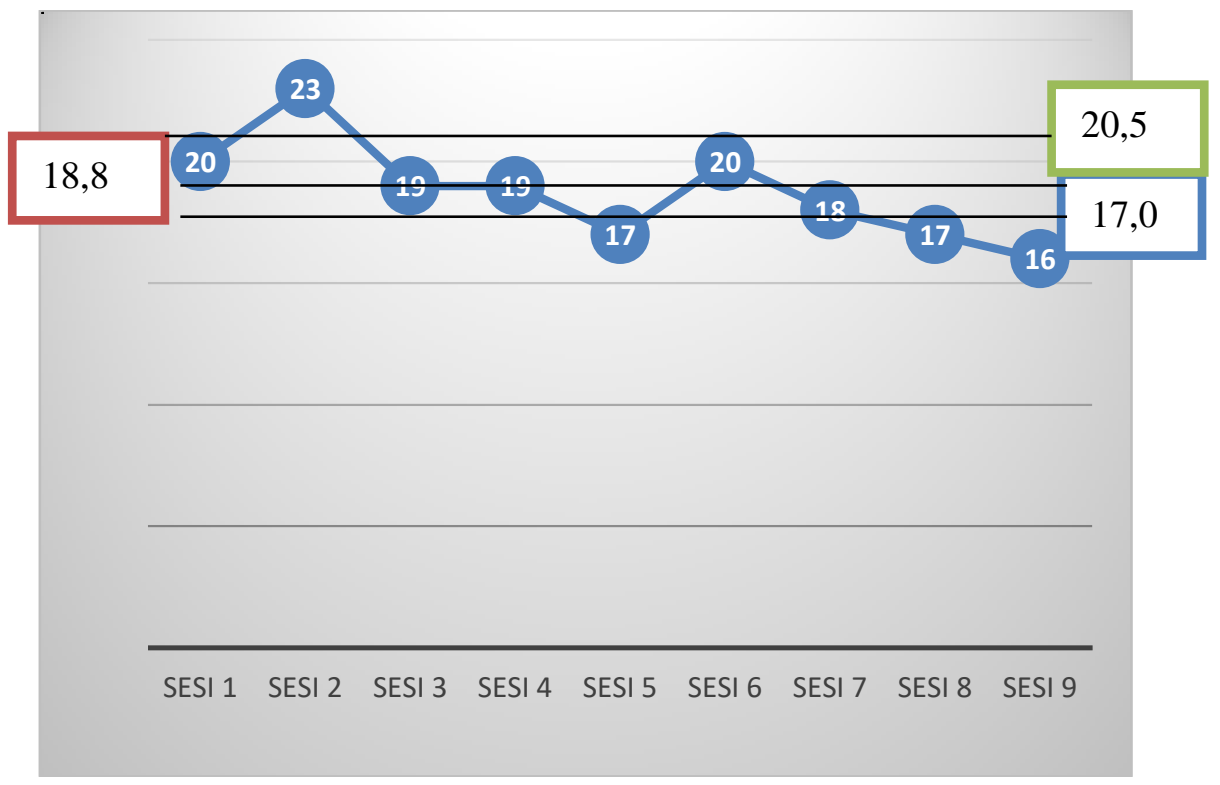

Grafik 9 Tingkat Stabilitas Baseline B

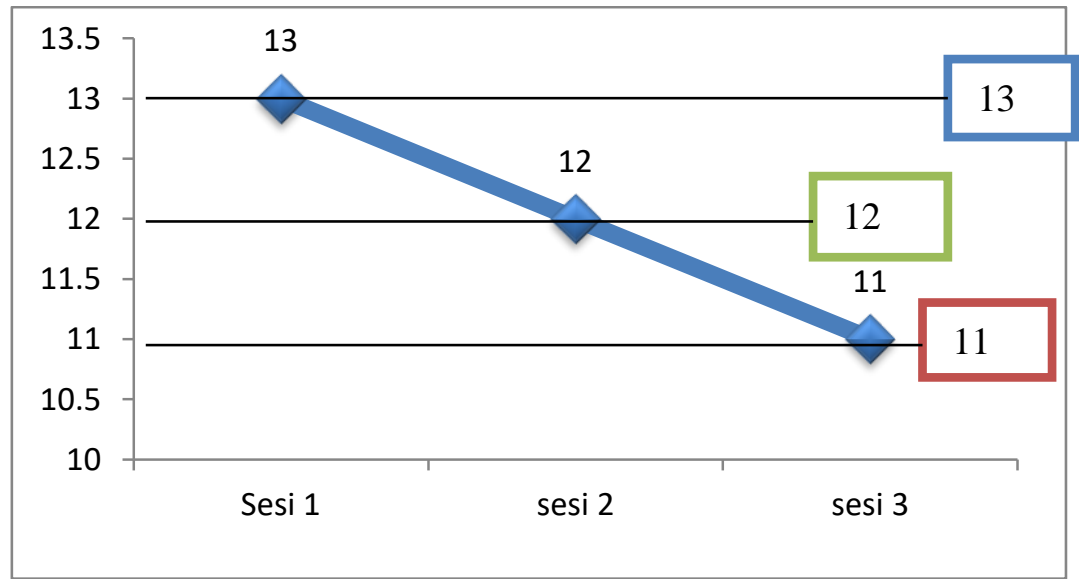

Grafik 10 Tingkat Stabilitas Baseline A2

4) Jejak Data

Tabel 6 Kecenderungan Jejak Data Responden AS

\begin{tabular}{|l|c|c|c|}
\hline Kondisi & A-1 & B & A-2 \\
\hline $\begin{array}{l}\text { Estimasi } \\
\text { kecenderungan arah }\end{array}$ & $(+)$ & $(+)$ & $(+)$ \\
\hline
\end{tabular}

Tabel 5 menunjukan kecenderungan jejak data tingkat kecemasan responden AS berada di level positif untuk fase baseline A1, baseline B dan fase baseline A2. 
5) Level stabilitas dan rentang

Dalam menentukan level stabilitas dan rentang, setelah dilakukan perhitungan pada fase baseline A1 data yang diperoleh stabil, fase baseline B stabil dan fase baseline A2 juga berada pada data stabil. Adapun rentang data fase baseline A2 berada pada 21 - 24, pada fase baseline B data stabil berada pada rentang 16 - 23 dan fase baseline A2 data satbil dengan rentang 11 - 13. Adapun cara menentukan level stabil yaitu dengan memasukan masing-masing kondisi angka terkecil dan angka terbesar pada masing-masing baseline, maka diperoleh tabel 7:

Tabel 7 Level Stabilitas dan Rentang Responden AS

\begin{tabular}{|l|c|c|c|}
\hline Kondisi & A-1 & B & A-2 \\
\hline Level Stabiitas & Stabil & Stabil & Stabil \\
\hline Rentang & $21-24$ & $16-23$ & $11-13$ \\
\hline
\end{tabular}

6) Level Perubahan

Untuk mengetahui level perubahan yaitu dengan cara menandai data pada hari pertama (H ke 1) dan terakhir, selanjutnya peneliti menghitung selisih kedua data tersebut. Jika di peroleh data (+) maka menujukkan arah yang membaik, namun jika menunjukan data (-) maka data menunjukan menurun.

Tabel 8 Level Perubahan Responden AS

\begin{tabular}{|l|c|c|c|}
\hline Kondisi & A-1 & B & A-2 \\
\hline \multirow{2}{*}{ Level Perubahan } & $21-22$ & $20-16$ & $13-11$ \\
\cline { 2 - 4 } & $(-1)$ & $(+4)$ & $(+2)$ \\
\hline
\end{tabular}

b. Analisis antar kondisi

1) Variabel yang dirubah

Variabel yang akan diubah dalam penelitian ini yaitu tingkat kecemasan responden AS pasca bencana longsor di Kampung Cibitung Desa Margamukti Kecamatan Pangalengan Kabupaten Bandung. Maka, pada data variabel yang diubah pada kondisi baseline 1 (A1) ke intervensi (B) adalah 1.

Tabel 9 Data Variabel Yang Diubah

\begin{tabular}{|l|c|c|}
\hline Perbandingan Kondisi & B/A1 & A2/B \\
& $2: 1$ & $3: 1$ \\
\hline Jumlah variabel yang diubah & 1 & 1 \\
\hline
\end{tabular}


2) Perubahan kecenderungan arah

Terdapat tiga perubahan kecenderiungan arah pada analisis dalam kondisi yaitu naik, turun atau tetap. Hal ini bertujuan untuk mengetahui perubahan yang terjadi. Untuk mengetahui kecenderungan arah tingkat kecemasan responden AS maka dapat dilihat berdasarkan tabel berikut:

Tabel 10 Data Kecenderungan Arah responden AS

\begin{tabular}{|c|c|c|}
\hline $\begin{array}{l}\text { Perbandingan } \\
\text { Kondisi }\end{array}$ & $\begin{array}{c}\mathrm{B} / \mathrm{A} 1 \\
2: 1\end{array}$ & $\begin{array}{c}\mathrm{A} 2 / \mathrm{B} \\
3: 2\end{array}$ \\
\hline $\begin{array}{l}\text { Perubahan } \\
\text { kecenderungan } \\
\text { Arah }\end{array}$ & $(+)$ & $(+)$ \\
\hline
\end{tabular}

Tabel diatas menunjukan tren penurunan tingkat kecemasan responden AS pasca bencana longsor yang ia lami. Hal ini menjelaskan bahwa REBT dapat menurunkan tingkat keemasan pasca bencana longsor.

3) Perubahan stabilitas dan efek

Perubahan stabilitas dan efek bertujuan untuk mengetahui stabilitas tingkat kecemasan responden pada masing-masing baseline baik baseline sebelum dilaksanakan intervensi maupun sesudah intervensi, maka hasilnya dapat dilihat melalui tabel berikut:

Tabel 11 Data Perubahan Kecenderungan Stabilitas dan Efek Responden AS

\begin{tabular}{|l|c|c|}
\hline Perbandingan Kondisi & B/A1 & A2/B \\
& $2: 1$ & $3: 2$ \\
\hline Perubahan stabilitas dan efek & Stabil ke Stabil & Stabil ke Stabil \\
\hline
\end{tabular}

4) Perubahan level data

Untuk mengetahui perubahan level data pada fase baseline 1 dan awal sesi pada intervensi yaitu dengan menentukan data point pada fase baseline A1 di sesi akhir dan sesi awal pada baseline B. Selanjutnya jika selisih keduanya menunjukan (+), maka terjadi kenaikan perubahan level data, (=) menunjukan tidak adanya perubahan dan jika (-) maka perubahan data menunjukan penurunan kevel data. Hasil penelitian menunjukan sebagai berikut: 
Tabel 12 Data Perubahan Level Tingkat Kecemasan Responden AS

\begin{tabular}{|l|c|c|}
\hline Perbandingan Kondisi & B/A1 & A2/B \\
& $2: 1$ & $3: 2$ \\
\hline \multirow{2}{*}{ Perubahan Level Data } & $21-20$ & $16-13$ \\
& $(+1)$ & $(+3)$ \\
\hline
\end{tabular}

5) Data yang overlap

Data overlap merupakan kesamaan data yang terjadi pada fase baseline A1 dengan intervensi (baseline B2). Menurut Juang (2006), menjelaskan bahwa semakin kecil presentase overlap maka semakin baik pengaruh intervensi terhadap target behavior. Berkaitan dengan terbut, maka data yang overlap sebagai berikut:

Tabel 13 Data Yang Overlap Pada Tingkat Kecemasan
Responden AS
\begin{tabular}{|l|c|c|}
\hline Perbandingan Kondisi & $\begin{array}{c}\text { B/A1 } \\
2: 1\end{array}$ & $\begin{array}{c}\text { A2/B } \\
3: 2\end{array}$ \\
\hline Presentase overlap & $\begin{array}{c}1: 9 \times 100 \% \\
(11,11 \%)\end{array}$ & $\begin{array}{c}0: 3 \times 100 \% \\
(0 \%)\end{array}$ \\
\hline
\end{tabular}

Berdasarkan tabel diatas, maka di ketahui bahwa responden AS, data yang overlap sebesar $11,11 \%$. Hal tersebut dikarenakan pada fase baseline B terdapat 1 data yang masuk pada fase baseline A1, sedangkan fase baseline A2 tidak terdapat data yang masuk pada fase baseline B. maka berdasarkan data tersebut pengaruh implementasi REBT berpengaruh terhadap pegurangan tingkat kecemasan pascabencana longsor

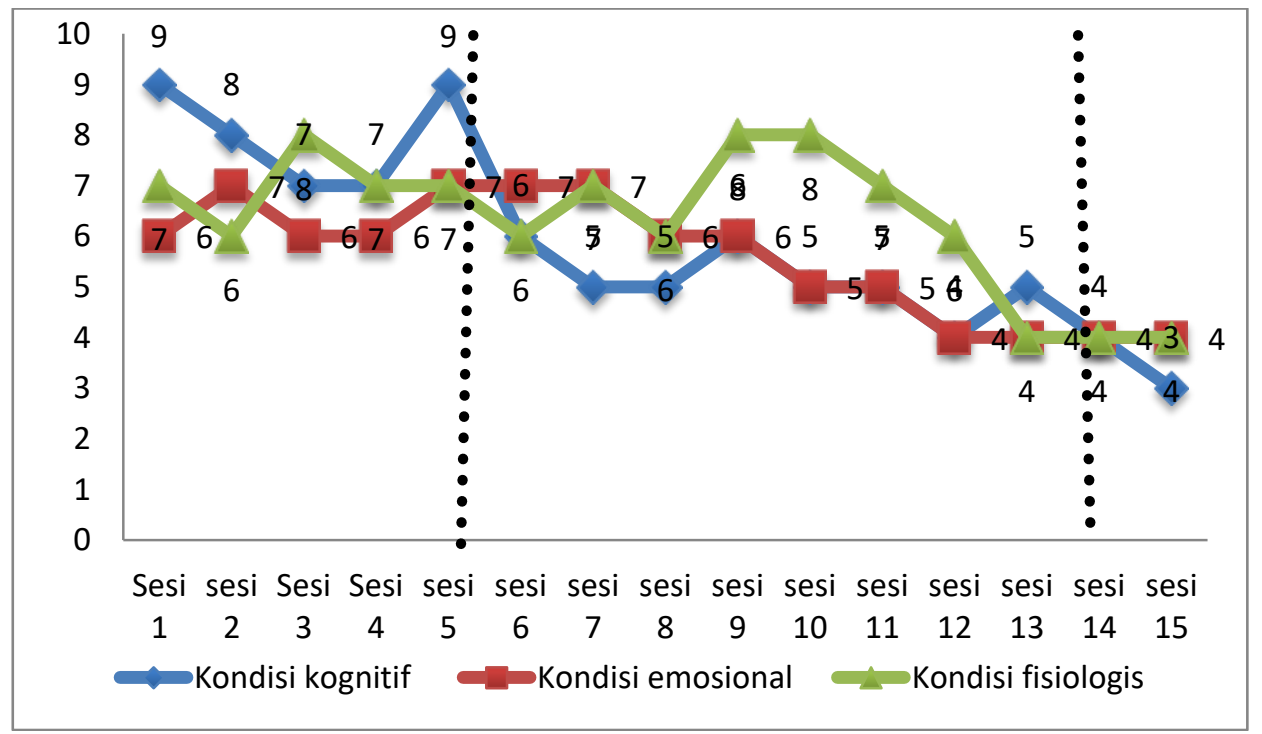

Grafik 11 Hasil Baseline A - B - A 
Pada grafik 11 menjelaskan bahwa pada fase baseline A1, B dan A2 mengalami kondisi yang naik turun. Pada aspek kognitif terlihat di baseline A1 mengalami penurunan dari sesi pertama sampai sesi ketiga, namun pada baseline B mengalami kenaikan skor di sesi kelima kemudian turun kembali sampai pada fase baseline A2. Hal tersebut menunjukkan bahwa REBT yang dikembangkan oleh Albert Ellis efektif untuk mengurangi tingkat kecemasan baik aspek kognitif, emosional maupun fisiologis. Penurunan tingkat kecemasan dapat dilihat pula pada grafik 11 berikut

Hasil penelitian secara umum bertujuan untuk mengetahui pengaruh implementasi rational emotif behavior therapy (REBT) terhadap pengurangan tingkat kecemasan responden AS pascabencana longsor dikampung Cibitung Desa Margamukti Kecamatan Pangaleengan. Dalam penelitian ini terdapat tiga tahapan utama yaitu tahap sebelum dilaksanakannya intervensi (fase baseline A1), tahap intervensi (fase baseline B) dan tahapan setelah dilaksanakan intervensi (fase baseline A2). Berkaitan dengan hal tersebut maka di peroleh hasil perbandingan terhadap ketiga tahapan tersebut.

1. Hasil Baseline $\mathrm{A}-\mathrm{B}-\mathrm{A}$

Berkaitan dengan permecahan masalah penelitian yang diajukan dengan model A-B-A menunjukkan adanya hubungan sebab akibat. Dalam melakukan penelitian dengan desain kasus tunggal menurut Hasselt dan Harsen dalam Sunanto (2006), menjelaskan bahwa selalu ada pengukuran target pencapaian behaviour pada fase baseline dan pengulangannya sekurang-kurangnya satu fase intervensi. Hasil perbandingan baseline A-B-A dapat dilihat pada grafik 12 berikut:

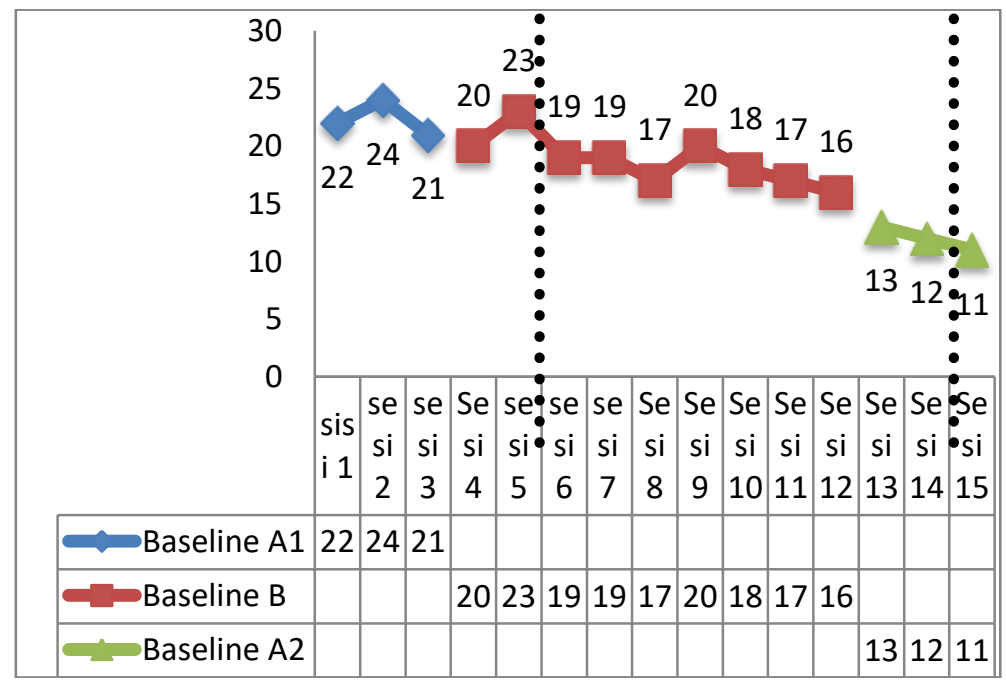

Grafik 12 Penurunan tingkat kecemasan Berdasarkan Sub-Aspek 
Pada grafik 12 dapat memberikan jawaban atas hipotesa penelitian bahwa implementasi Rational Emotive Behavior Terapy (REBT) berpengaruh terhadap menurunnya tingkat kecemasan penyintas bencana longsor.

2. Hasil analisis tingkat kecemasan dalam kondisi responden AS

Dalam hal ini analisis data dalam kondisi bertujuan untuk mengetahui pengaruh intervensi terhadap sasaran variabel yang dirubah (tingkat kecemasan). Hasil analisis tingkat kecemasan antar kondisi Responden AS Secara umum intervensi yang dilakukan oleh peneliti dinyatakan efektif. Perbandingan antara fase baseline A1 fase baseline B dan fase baseline B - fase baseline A2 jumlah variabel yang dirubah yaitu tingkat kecemasan responden. Dilihat dari perubahan kecenderungan arah pada A1 dengan B memiliki kesamaan dengan fase baseline B dengan A2.yang menunjukan arah $(+)$. Sedangkan stabilitas dan efek yang terjadi dari baseline A1 baseline B terdapat peningkatan level data sebanyak (+1) sedangkan baseline B baseline A2 terjadi peningkatan level data sebanyak (+3). Perbedaan yang terjadi juga di tunjukan pada jumlah presentase everlap dimana baseline A1 - baseline B memiliki nilai $11,11 \%$ sedangkan baseline B - baseline A2 tidak terdapat perubahan level data overlap

\section{KESIMPULAN}

Berdasarkan hasil penelitian implementasi REBT terhadap pengurangan tingkat kecemasan klien AS menunjukkan penurunan tingkat kecemasan. Hal ini memberikan jawaban bahwa REBT efektif terhadap menurunnya gangguan kecemasan korban bencana longsor.baik secara kognitif, emosional maupun fisiologis. Metode yang digunakan peneliti dalam membantu memecahkan permasalahan yang dihadapi klien dan keluarganya adalah social case work dan social group work. Metode social case work ditujukan untuk membantu memecahkan masalah yang dihadapi klien secara individual yaitu untuk membantu mengatasi masalah psikososialnya yang dialaminya, sedangkan metode social group work digunakan untuk membantu memecahkan permasalahan keluarga.

Hasil yang dicapai dalam intervensi adalah adanya perubahan gangguan kecemasan. Perubahan yang ditunjukkan klien AS yaitu siap menghadapi kehidupan pasca bencana dan kelekatan keluarga semakin terjalin. Walaupun dalam intervensi ini menghasilkan perubahan terhadap klien dan keluarganya namun demikian peneliti menyadari, bahwa perilaku positif klien tersebut belum sepenuhnya terinternalisasi secara kuat dalam diri klien. Perilaku negatif klien dapat saja timbul kembali, dan bahkan meningkat. Hal ini dikarenakan kondisi pasca 
bencana sangat rentan terhadap perubahan status sosial sehingga dapat menimbulkan kembali gangguan- gangguan psikis lainnya disisi lain.

\section{DAFTAR PUSTAKA}

Adi, F. (2012). Pengantar Kesejahteraan Sosial. Bandung: Refika Aditama.

Cooper, M., \& Lesser, J. G. (2014). Clinical Social Work Practice: An Integrated Approach. Pearson.

Coppola, D. P., \& Maloney, E. K. (2009). Communicating Emergency PreparednessStrategies for Creating a Disaster Resilient Public, CRC.

Davidson, G., Neale, J. M., \& Kring, A. M. (2006). Psikologi Abnormal. Jakarta: Raja Grafindo Persada.

Gladding, S. T. (2012). Konseling profesi yang menyeluruh. Jakarta: Indeks.

Milner, J., \& O’brien. (2002). Asessment in Social Work. Palgrave Macmillan.

Komalasari, dkk. (2011). Asessment Teknik Non Tes dalam Prespektif BK Komperehensif. Jakarta : PT Indeks.

O'Byrne, P., \& Milner, J. (2002) Assessment in Social Work Second Edition, Palgrave Macmillan, New York.

Romsan, A. (2003). Pengantar Hukum Pengungsi Internasional. Bandung: Sanic Offset.

BNPB. (2010). RencanaAksiNasionalPenanggulangan Bencana 2010- 2012, Jakarta

Sarandria. (2012). Efektifitas Cognitive Behavior Therapy (CBT) untuk Meninngkatkan Self Esteem Pada Dewasa Muda. Tesis. Depok Universitas Indonesia.

Sunanto, J., Takeuchi, K., \& Nakata, H. (2006). Penelitian dengan Subjek Tunggal. Bandung: UPI Pres.

Sunanto, J., Takeuchi, K., \& Nakata, H. (2005). Pengantar Penelitian dengan Subjek Tunggal. Universitas Tsukuba: Crice.

Susiladiharti, \& Nelson, A. (2014). Teori Pekrejaan Sosial Modern. Jakarta: Samudra Biru.

Safaria, T. \& Saputra, N. E. (2007). Manajemen Emosi. Jakarta: Bumi Askara

Undang-UndangRepublik Indonesia No. 11 tahun 2009, Tentang kesejahteraan Sosial

Undang-UndangRepublik Indonesia No. 24 tahun 2007, Tentang Penanggulangan Bencana

UNDP (1992), TinjauanUmum Manajemen Bencana-Program Pelatihan Manajemen Bencana. Chambrige, United Kingdom

UNDP/UNDRO, 1992. Introduction to Hazard 1 st Edition, Disaster Management Training Programme. University Wiconsion, US.

Indrati, Y. dkk. (2009). Modul Ajar Pengintegrasian Pengurangan Risiko Bencana Longsor. Jakarta: Pusat Kurikulum Badan Penelitian dan engembangaan Kementerian Pendidikan Nasional. 